\title{
Spatial distribution of macro- and micro- nutrients in soils of Saharsa district of Bihar
}

AJEET KUMAR AUTHOR FOR CORRESPONDENCE :

AJEET KUMAR, Regional Research Station, Madhopur, WEST CHAMPARAN (BIHAR) INDIA Email: ajeetrau@gmail.com
Received : 08.08.2015; Revised : 07.11.2015; Accepted : 22.11.2015

\section{Summary}

The soils samples (0-30 cm depth) were collected from ten block of Saharsa district. The study of macro- and micro-nutrients of some soils of the district was carried out to assess the soil fertility and micro- nutrient status and their relationship with each other. Soils were analyzed for DTPA extractable $\mathrm{Zn}, \mathrm{Cu}, \mathrm{Mn}, \mathrm{Fe}$ and hot water extractable $\mathrm{B}$ in relation to chemical properties of soils. The mean values for DTPA-extractable $\mathrm{Zn}, \mathrm{Cu}, \mathrm{Mn}, \mathrm{Fe}$ and hot water extractable B were $2.36,1.52,113.93,766.03$ and $0.10 \mathrm{mg} \mathrm{kg}^{-1}$, respectively. The mean values of available $\mathrm{N}, \mathrm{P}_{2} \mathrm{O}_{5}, \mathrm{~K}_{2} \mathrm{O}$ and $\mathrm{SO}_{4}-\mathrm{S}$ were $382.04,38.31,208.86$ and $22.65 \mathrm{~kg} \mathrm{ha}^{-1}$, respectively. Distribution of micronutrients cations were influenced positively by $\mathrm{pH}, \mathrm{EC}$ and organic carbon content of the soil. Results indicated that the micro- nutrient cations were significantly correlated with each other, suggesting about the dynamic equilibrium among them.

Key words : Soil fertility, Macro- and micro-nutrients, Soil reaction, DTPA

How to cite this article : Kumar, Ajeet (2015). Spatial distribution of macro- and micro- nutrients in soils of Saharsa district of Bihar. Asian J. Soil Sci., 10(2) : 276-282. 